
higher education? Cuadernos de Psicología del Deporte, Vol 19(2), 265-277

\title{
Is lifestyle a determining factor for body satisfaction in higher education?
}

\author{
¿Estilo de vida es un factor determinante para la satisfacción corporal \\ en la educación superior?
}

\section{¿O estilo de vida é um fator determinante para a satisfação corporal no ensino superior?}

\author{
Nascimento Junior, Jose Roberto Andrade do. ${ }^{1}$, Moreira, Caio Rosas ${ }^{2}$, Gonçalves, Marina Pereira ${ }^{1}$, \\ Bezerra, Thainã Alves ${ }^{1}$, Souza Filho, Anastácio Neco ${ }^{1}$, Fiorese, Lenamar ${ }^{2}$, Carvalho, Ferdinando \\ Oliveira $^{1}$ \\ ${ }^{1}$ Universidade Federal do Vale do São Francisco, ${ }^{2}$ Universidade Estadual de Maringá.
}

\begin{abstract}
People's lives are in increasingly hurry due to several factors interfering in their lifestyle. However, little is known about how much such lifestyle affects one's body satisfaction. This study investigated the impact of lifestyle on body satisfaction of the students, professors and administrative staff of a Brazilian university. A total of 659 students $(n=460)$, professors $(n=49)$ and administrative staff $(n=150)$ of a federal northeastern Brazilian university answered the Body Satisfaction Situational Scale and Fantastic Lifestyle Questionnaire. Linear regression indicated that work has a positive impact on the satisfaction with external parts for students, while, for the administrative staff, it was having lower alcohol consumption and being with family/friends, for professors, body satisfaction suffered impact from higher alcohol consumption, aggressive behavior, sleep deprivation, lower stress management and unsafe attitudes $(\mathrm{p}<.05)$. It is concluded that lifestyle profile can be considered a determining factor for body satisfaction in higher education, contributing or not for higher body satisfaction.
\end{abstract}

Keywords: Lifestyle; Body image; Satisfaction; University.

\section{RESUMEN}

La vida de las personas están cada vez más corrida a varios factores que afectan el estilo de vida. Sin embargo, poco se sabe cómo este estilo interfiere en la satisfacción con el cuerpo de la personas. Este estudio investigó el impacto del estilo de vida en la satisfacción corporal de los estudiantes, profesores y personal administrativo de una universidad brasileña. Un total de 659 estudiantes $(n=460)$, profesores $(n=49)$ y técnicos $(n=150)$ de una universidad federal en el noreste del Brasil, respondieron la Escala Situacional de Satisfacción del Cuerpo y el Cuestionario "Estilo de Vida Fantástico". El trabajo ha impactado positivamente la satisfacción de las partes 


\section{Nascimento Filho, J.R.A.; Moreira, C.R.; Gonçalves, M.P; Bezerra, T.A.; Souza Filho, A.N.; Fiorese, L.; Carvalho, F.O}

externas para los estudiantes, mientras para los técnicos fue el bajo consumo de alcohol y estar entre familia/amigos que ha impactado, y los profesores, la satisfacción corporal sufrió impacto del mayor consumo de alcohol, comportamiento agresivo, privación de sueño, menor control del estrés y actitudes inseguras $(p<.05)$. Concluye se que el perfil de estilo de vida puede ser considerado un factor determinante para la satisfacción corporal en la educación superior, que contribuyen o no a una mayor satisfacción corporal.

Palabras clave: Estilo de Vida; Imagen corporal; Satisfacción; Universidades.

\section{RESUMO}

A vida das pessoas está cada vez mais corrida devido a diversos fatores que interferem no estilo de vida. No entanto, pouco se sabe o quanto que este estilo interfere na satisfação corporal das pessoas. Este estudo investigou o impacto do estilo de vida na satisfação corporal de estudantes, professores e técnicos administrativos de uma universidade brasileira. Um total de 659 alunos $(n=460)$, docentes $(n=49)$ e técnicos $(n=150)$ de uma universidade federal do nordeste brasileiro, responderam a Escala Situacional de Satisfação Corporal e o Questionário "Estilo de Vida Fantástico". Para os alunos o trabalho impactou positivamente a satisfação das partes externas, enquanto para os técnicos foi o menor consumo de álcool e estar entre família/amigos, já os docentes, a satisfação corporal sofreu impacto do maior consumo de álcool, comportamento agressivo, privação de sono, menor controle do estresse e atitudes não seguras $(\mathrm{p}<.05)$. Conclui-se que o perfil de estilo de vida pode ser considerado um fator determinante para a satisfação corporal no ensino superior, contribuindo ou não para uma maior satisfação corporal.

Palavras chave Modo de vida; Imagem corporal; Satisfação; Universidades.

\section{INTRODUCTION}

Does the practice of physical exercise provide the practitioner with body satisfaction? Can a healthy lifestyle also provide such satisfaction? Regardless of lifestyle, can practicing physical activity improve body satisfaction? Physical exercise and body satisfaction are very interconnected with each other, since one promotes both physical and psychological changes to the other (Blanco, Benavides, Tristan, \& Mayorga-Vega, 2017; Casquinho, Cheira, Roseiro, Neves, Martins, \& Marques, 2013; Laus, Kakeshita, Costa, Ferreira, Fortes, \& Almeida, 2014; Neves, Martins, Souza, \& Junior, 2015). Therefore, maintaining a healthy lifestyle is seen as a determining factor to live better, having both greater longevity and better quality of life (Silva, Brito, \& Amado, 2014). However, little is known about the effect that lifestyle has on the body satisfaction of those who practice physical exercise. According to the literature review carried out, few studies were found that specifically investigated the relationship between lifestyle perception and body satisfaction in physical exercise practitioners, specially in the university context as a whole, analyzing students, professors and administrative staffs, as we present throughout this study.

Body satisfaction is a general component of the multidimensional perception related to the contentment with the parts of the body, satisfaction with weight and body image (Cardoso, Almeida Zequinão, Felizola, Ceola, \& Matos, 2011). On the other hand, body image is the view and judgment a person has over his/her own body, based on cultural standards set by society (Casquinho et al., 2013). Thus, the search for an ideal body is usually guided by beauty standards often related to weight reduction and/or lean mass gain, which will lead people to look for a physical activity (Mendonça, Sousa, \& Fernandes, 2012). The relationship of body image with body patterns is directly connected to the standards imposed by society; something that has been identified by the sociocultural theory in different countries (Groesz, Levine, \& Murnen, 2002).

This theory states that specific body image patterns are directly influenced by the media, parents and the comparison with their peers as 


\section{Lifestyle and body satisfaction in higher education}

well (Rodgers, Chabrol, \& Paxton, 2011). Therefore, body satisfaction is something derived from this sociocultural influence that people suffer daily when comparing their own appearance with the internalization of local media standards (Rodgers et al., 2011). Thus, engaging in physical exercises can help the person to achieve greater body satisfaction (Cardoso et al., 2011). However, each person who practices these activities has a different lifestyle, which can often be differentiated by healthy habits when outside this physically active context.

Radel, Pelletier, Pjevac, \& Cheval (2017) regard healthy habits as behaviors that had become automatic through repeated practice. In this sense, the authors evaluated the relationship between different forms of self-determined motivation and the behavioral automatism associated with different domains of life among French university students. Participants were introduced to 12 behaviors (playing video games, washing the car, going to the movies, running, drinking alcohol, brushing teeth, going to the library, calling parents, eating chips, smoking cigarettes, going to the gym, using the vacuum cleaner) at random. The authors verified that self-determined motivation was more associated with behavioral automaticity. These results suggest that habits can be determinant not only to perform an activity, but, above all, to maintain it, and it is therefore relevant to understand how lifestyle interferes in body satisfaction. In addition, Guedes \& Grondin (2002) verified the relationship between the adoption of healthy habits with dietary indicators, practice of physical activity and control of body weight among Brazilian adolescents. Their results indicated that the adolescents showed a high level of perception about healthy habits, however, no evidence was found that these perceptions could effectively influence in having appropriate behaviors, related to feeding and physical activity.

Therefore, several factors beyond the physical exercise practice environment will play a key role in the way a person behaves routinely. The environment and social groups one is inserted in, the socioeconomic conditions, health quality and concern, in addition to the adaptation to stress caused by work and everyday life, are factors that interfere in a person's lifestyle (Añez, Reis, \& Petroski, 2008; Pletsch, Reuter, Lasch, Vieira, Reckziegel, \& Pohl, 2014). On the other hand, lifestyle resulting from all these factors is considered as a relevant element for people's health (Silva et al., 2014). Rosa, García Cantó, \& Carrillo (2018) found that children who practice more exercise are healthier and more physically capable than their peers who practice less exercises, being this fundamental to develop from an early age a healthy lifestyle for the person in the future ages. Thus, a lifestyle supported by healthy behavior can make people more concerned with their own body, whereas physical exercise practitioners are more satisfied with their body image (Abbott \& Barber, 2011; Casquinho et al., 2013).

Some studies have shown the positive relationship that the practice of physical activity and sport have on the practitioners' body satisfaction (Abbott \& Barber, 2011; Laus et al., 2014; Mendonça et al., 2012). In the Brazilian context, Santos, Tassitano, Nascimento and Petribú (2011) analyzed the association of body satisfaction with nutritional status, sociodemographic factors, lifestyle and health perception of adolescents, finding a prevalence of high body dissatisfaction in both sexes. While boys and students with low weight had a greater desire to increase their weight, girls with less than three meals per day, with higher income and excess weight, would like to reduce their body mass. More recently, Shirasawa et al. (2015) investigated the relationship between distorted body image and lifestyle of Japanese adolescents and found that boys tended to underestimate body mass while girls overestimated their body mass. In addition, lifestyle factors associated with body image distortion differed by sex, with exercise affecting the perception of body image in boys and after-dinner snacks affecting body 


\section{Nascimento Filho, J.R.A.; Moreira, C.R.; Gonçalves, M.P; Bezerra, T.A.; Souza Filho, A.N.; Fiorese, L.; Carvalho, F.O}

image perception among girls. Thus, lifestyle can lead to adolescents' body image distortion.

Such evidences highlight the positive role that a healthy behavior (exercise practice) has in favoring the satisfaction of one's own body image. However, most of these studies were conducted with high school students, that is, adolescents. Therefore, little is known about the magnitude of lifestyle effect on the perception of body satisfaction in the university context, specifically in students, professors and administrative technicians, since each person, even practicing any type of exercise, has different lifestyles according to daily duties. This is the gap the present research aims to explore.

In this sense, the present study investigated the impact of lifestyle perception on the body satisfaction of the students, professors and administrative staff of a Brazilian northeastern federal university, also comparing life style and body satisfaction among groups.

\section{METHODS}

\section{Participants}

All of the students, professors and administrative staff who used to practice weight training were invited to participate in the Extension Project referred to as 'University Fitness Center' of a federal northeastern Brazilian university, with a total of 702 subjects. However, 43 subjects were excluded because they did not answer all the questionnaires. Thus, a total of 659 individuals (389 women and 270 men), being students $(\mathrm{n}=460)$, professors $(\mathrm{n}=49)$ and administrative staff $(n=150)$ were part of this study. Participants' average age was $24.41 \pm 5.59$ years for students; $38.82 \pm 8.82$ years for professors; and $36.10 \pm 9.06$ years for administrative staff. All participants voluntarily participated by signing an informed consent term. Inclusion criteria were the following: 1) minimum age of 18 years old; 2 ) a minimum training frequency of
4 times a week; and 3) presence in $75 \%$ of the training.

\section{Instruments}

The Body Satisfaction Situational Scale (Hirata \& Pilati, 2010) was used in order to measure body satisfaction. The scale evaluates momentary satisfaction with the body parts and the body as a whole. This instrument has 23 items divided into 4 dimensions: dissatisfaction with fat, external parts, satisfaction with muscles and lower parts. For each item the participant should answer, in a Likert scale, the degree of agreement (I strongly disagree $=1$, I strongly agree $=5)$.

Lifestyle was measured by using the questionnaire referred to as 'Fantastic Lifestyle' (Wilson, Nielsen, \& Ciliska, 1984), adapted and validated for the Brazilian context by Añes et al. (2008). The instrument evaluates habits and behaviors in relation to lifestyles suitable for health. The questionnaire has 25 items that explore nine fields of physical, psychological and social components of lifestyle represented by the acronym "FANTASTIC": (F) Family and Friends; (A) Physical activity/Associativism; (N) Nutrition; (T) Tobacco; (A) Alcohol and other drugs; (S) Sleeping / Stress; (T) Type of behavior; (I) Introspection; (C) - Career/Job. The items have five options for answering with a numeric value ranging from 0 for the first column to 4 for the last column. The result of each factor is calculated by the average of its respective items. The sum of all items provides an overall score that classifies individuals from 0 to 100 points.

\section{Procedures}

Data Collection. Initially, the authorization for carrying out the research was requested to the extension project coordination. Data collection occurred in the first half of 2015 at the university and sites where the extension project was being developed. Participants were invited to 


\section{Lifestyle and body satisfaction in higher education}

participate in the study by signing the Informed Consent Term. The questionnaires were collectively applied, by properly trained Physical Education and Psychology students, and answered individually with an average duration of 30 minutes.

Data analysis. Preliminary data analysis was conducted by using Kolmogorov-Smirnov normality test. Since the data did not have a normal distribution, Median (Md) and Quartiles (Q1-Q3) were used as descriptive measures. Kruskal-Wallis test was used for group comparisons (Students, Professors and Administrative Staff), followed by MannWhitney U test for group pairs. Spearman's rank correlation $(\mathrm{p}<.05)$ was used in order to evaluate the relationship between body satisfaction and lifestyle of the athletes. These analyzes were conducted through SPSS software version 22.0.

In order to verify the impact of lifestyle on body satisfaction of the students, professors and administrative staff, regression models were performed with the variables that had a significant correlation $(p<.05)$. The existence of outliers was assessed by using the Mahalanobis square distance $\left(\mathrm{DM}^{2}\right)$, and the univariate normality of the variables was evaluated through the asymmetry coefficients $(I S k I<3)$ and kurtosis $(I K u I<10)$ univariate and multivariate. Since the data were not normally distributed, the BollenStine Bootstrap method (2000 samples) was used to correct the value of the coefficients estimated by the Maximum Likelihood method (Marôco, 2011), implemented in the AMOS software version 22.0. The Bootstrapping technique (Marôco, 2011) was applied in order to verify the suitability of the sample for the analysis suggested, using the Maximum Likelihood method. There were no values of $\mathrm{DM}^{2}$ which indicated the existence of outliers, nor sufficiently strong correlations among the variables that indicated multicollinearity (Variance Inflation Factors <5.0). Starting from Kline's recommendations (2012), the interpretation of the regression coefficients had as reference: little effect for coefficients $<.20$, an average effect for coefficients up to .49 , and a strong effect for coefficients $>.50(\mathrm{p}<.05)$.

Ethical Considerations. This research is integrated into the extension project referred to as 'University Fitness Center' under the legal opinion CAEE $\mathrm{n}^{0} 5931.0 .000 .441-10$ of the University's Committee on Ethical Research with Humans.

\section{RESULTADOS}

Table 1 shows a significant difference considering dissatisfaction with fat among the students and administrative staff $(p=.019)$, indicating that the administrative staff $(x=3.62)$ was rather more dissatisfied in relation to body fat than the students $(x=3.38)$. In relation to the external parts $(\mathrm{p}=.001)$, the professors $(\mathrm{x}=3.80)$ had a higher body satisfaction compared to students $(x=3.38)$ and administrative staff $(x=3.40)$. There was a significant difference $(p=.043)$ considering satisfaction with the muscles among the students $(x=2.54)$ and professors $(x=2.75)$, indicating that the professors were more satisfied.

When comparing lifestyle between groups (Table 2), there were differences in the field of physical activity $(p=.028)$, showing that the students practice more physical activity when compared to the professors. Regarding the alcohol field $(p=.033)$, it was found that the professors had lower scores when compared to the students and administrative staff, which shows that they consume more alcohol. Considering the sleeping field, safety belt, stress and safe sex $(p=.002)$, the students $(M d=3.00)$ showed lower values when compared to the professors $(\mathrm{Md}=3.20)$ and to the administrative staff $(\mathrm{Md}=3.20)$, which indicates that they have these types of behavior more frequently. Finally, concerning the work field $(\mathrm{p}=.001)$, the students $(\mathrm{Md}=3.00)$ showed less satisfaction with their job when compared to the professors $(\mathrm{Md}=4.00)$ and administrative staff $(\mathrm{Md}=4.00)$. 
Table 1. Comparison the perception of body satisfaction between students, professors and administrative staff participating in the extension project "University Gym" of Univasf.

\begin{tabular}{|c|c|c|c|c|}
\hline \multirow[b]{2}{*}{ Body Satisfaction } & Students $(n=460)$ & Professors $(n=49)$ & Staff $(n=150)$ & \multirow[b]{2}{*}{$P$} \\
\hline & $\begin{array}{c}\mathrm{x}(\mathrm{sd}) \\
\mathrm{Md}(\mathrm{Q} 1-\mathrm{Q} 3)\end{array}$ & $\begin{array}{c}\text { x (sd) } \\
M d(Q 1-Q 3)\end{array}$ & $\begin{array}{c}\mathrm{x}(\mathrm{sd}) \\
\mathrm{Md}(\mathrm{Q} 1-\mathrm{Q} 3)\end{array}$ & \\
\hline Dissatisfaction-Fat & $\begin{array}{c}3.38(.89)^{\mathrm{a}} \\
3.43(2.71 ; 4.14)\end{array}$ & $\begin{array}{c}3.57(.80) \\
3.71(3.00 ; 4.00)\end{array}$ & $\begin{array}{c}3.62(.730 \\
3.64(3.14 ; 4.18)\end{array}$ & $.019 *$ \\
\hline External Parts & $\begin{array}{c}3.38(.76)^{b} \\
3.50(3.00 ; 4.00)\end{array}$ & $\begin{array}{c}3.80(.71)^{\mathrm{c}} \\
4.00(3.25 ; 4.25)\end{array}$ & $\begin{array}{c}3.40(.73) \\
3.50(3.00 ; 4.00)\end{array}$ & $.001 *$ \\
\hline $\begin{array}{l}\text { Satisfaction- } \\
\text { Muscle }\end{array}$ & $\begin{array}{c}2.54(.72)^{\mathrm{d}} \\
2.50(2.03 ; 3.00)\end{array}$ & $\begin{array}{c}2.75(.65) \\
2.75(2.31 ; 3.13)\end{array}$ & $\begin{array}{c}2.65(.72) \\
2.63(2.13 ; 3.13)\end{array}$ & $.043 *$ \\
\hline Lower Parts & $\begin{array}{c}2.89(.63) \\
3.00(2.50 ; 3.25)\end{array}$ & $\begin{array}{c}2.96(.46) \\
3.00(2.75 ; 3.25)\end{array}$ & $\begin{array}{c}2.96(.57) \\
3.00(2.50 ; 3.50)\end{array}$ & .380 \\
\hline
\end{tabular}

*Statistical difference $\mathrm{p}<0.05$ (Kruskal-Wallis test) between: a) Students and Staff; b) Students and Professors; c) Professors and Staff; d) Students and Professors.

When analyzing the correlation between body satisfaction and student's lifestyle domains, there was a significant correlation $(\mathrm{p}<.05)$ only between 'external parts and job' $(\mathrm{r}=.18)$. Among the professors, there was a significant correlation $(\mathrm{p}<.05)$ between the 'lower parts and alcohol' ( $\mathrm{r}$ $=-.30$ ); 'sleep, seat belt, stress, and safe sex' with satisfaction with muscles $(\mathrm{r}=-.32)$; and 'type of behavior and lower parts' $(\mathrm{r}=-.36)$. Considering the administrative staff, there was a significant correlation $(\mathrm{p}<.05)$ between 'external parts and family/friends' $(\mathrm{r}=.18)$; and 'external parts and alcohol' $(\mathrm{r}=.20)$.

In order to verify the impact of lifestyle domains on the body satisfaction of students, professors and administrative staff, Path Analysis was carried out among the variables that were significantly correlated $(\mathrm{p}<.05)$. In the students' model (Figure 1), it was found that the job satisfaction explains only $2 \%$ of the variability with the external parts of the body [GFI=.99; $\mathrm{CFI}=.99 ; \quad \mathrm{RMSEA}=0.08 ; \mathrm{p}=0.061]$, with $\mathrm{a}$ significant trajectory (regression coefficient) (Standard Error $/ \mathrm{SE}=.06$; Critical ratio/ $\mathrm{CR}=2.63$, $\mathrm{p}=.009)$. It is noteworthy that the increasing satisfaction with the job has a weak effect $(\beta<.20)$ on the satisfaction with hair, face and skin. This finding indicates that the increase of 1 standard deviation in the satisfaction with work causes an increase of .15 standard deviation in the satisfaction with external parts.

When analyzing the impact of the lifestyle domains on the body satisfaction of professors (Figure 1), it was found that the alcohol and the type of behavior explained $25 \%$ of the satisfaction variability with the lower parts [GFI $=.99 ; \mathrm{CFI}=1.00$ RMSEA $=0.10 ; \mathrm{p}=0.007]$. Regarding the individual trajectories, it was found that the alcohol field trajectory $(\mathrm{SE}=.07$, $\mathrm{CR}=-2.84 ; \mathrm{p}=.004)$ and behavior $(\mathrm{SE}=.06, \mathrm{CR}=-$ 2.67, $\mathrm{p}=.008)$ had a significant effect on the satisfaction with the lower parts. Such results indicate that the decrease in both, alcohol consumption and anger and irritability behavior has negative and moderate effects $(\beta>.20)$ on satisfaction with glutes, hips and legs. This finding indicates that the increase of 1 standard deviation in the fields of alcohol and behavior 


\section{Lifestyle and body satisfaction in higher education}

(decrease in alcohol consumption and lower angry or aggressive behavior) causes the reduction of .36 and .33 standard deviation of lower body parts satisfaction, respectively.

Table 2. Comparison of lifestyle domains between students, professors and administrative staff participating in the extension project "University Gym" of Univasf.

\begin{tabular}{|c|c|c|c|c|}
\hline \multirow{2}{*}{$\begin{array}{l}\text { Lifestyle } \\
\text { Domain }\end{array}$} & Students $(\mathrm{n}=460)$ & Professors $(n=49)$ & Staff $(n=150)$ & \multirow{2}{*}{$P$} \\
\hline & $\begin{array}{c}\mathrm{x}(\mathrm{sd}) \\
\mathrm{Md}(\mathrm{Q} 1-\mathrm{Q} 3)\end{array}$ & $\begin{array}{c}\mathrm{x}(\mathrm{sd}) \\
\mathrm{Md}(\mathrm{Q} 1-\mathrm{Q} 3)\end{array}$ & $\begin{array}{c}x(s d) \\
M d(Q 1-Q 3)\end{array}$ & \\
\hline $\begin{array}{l}\text { Family and } \\
\text { Friends }\end{array}$ & $\begin{array}{c}3.14(.88) \\
3.50(2.50 ; 4.00)\end{array}$ & $\begin{array}{c}3.38(.79) \\
3.50(3.00 ; 4.00)\end{array}$ & $\begin{array}{c}3.14(.90) \\
3.25(2.50 ; 4.00)\end{array}$ & .190 \\
\hline Physical Activity & $\begin{array}{c}1.43(1.14)^{\mathrm{a}} \\
1.00(0.50 ; 2.00)\end{array}$ & $\begin{array}{c}1.00(.91) \\
1.00(0.50 ; 1.50)\end{array}$ & $\begin{array}{c}1.24(1.15) \\
1.00(0.00 ; 2.00)\end{array}$ & $.028 *$ \\
\hline Nutrition & $\begin{array}{c}2.13(.88) \\
2.00(1.33 ; 2.67)\end{array}$ & $\begin{array}{c}2.39(.89) \\
2.33(1.67 ; 3.25)\end{array}$ & $\begin{array}{c}2.08(.95) \\
2.00(1.33 ; 2.67)\end{array}$ & .150 \\
\hline Tobacco & $\begin{array}{c}3.48(.52) \\
3.75(3.25 ; 3.75)\end{array}$ & $\begin{array}{c}3.39(.47) \\
3.50(3.25 ; 3.75)\end{array}$ & $\begin{array}{c}3.47(.43) \\
3.50(3.25 ; 3.75)\end{array}$ & .055 \\
\hline Alcohol & $\begin{array}{c}3.53(.66) \\
3.67(3.33 ; 4.00)\end{array}$ & $\begin{array}{c}3.22(.82)^{\mathrm{b}} \\
3.67(2.33 ; 4.00)\end{array}$ & $\begin{array}{c}3.47(.75) \\
3.67(3.33 ; 4.00)\end{array}$ & $.033 *$ \\
\hline $\begin{array}{l}\text { Sleeping, seatbelt, } \\
\text { stress e safe sex }\end{array}$ & $\begin{array}{c}2.96(.58)^{\mathrm{c}} \\
3.00(2.60 ; 3.40)\end{array}$ & $\begin{array}{c}3.18(.53) \\
3.20(2.80 ; 3.60)\end{array}$ & $\begin{array}{c}3.11(.52) \\
3.20(2.80 ; 3.40)\end{array}$ & $.002 *$ \\
\hline Type of behavior & $\begin{array}{c}2.12(.81) \\
2.00(1.50 ; 2.50)\end{array}$ & $\begin{array}{c}2.05(.89) \\
2.00(1.50 ; 2.50)\end{array}$ & $\begin{array}{c}2.25(.87) \\
2.00(1.50 ; 3.00)\end{array}$ & .176 \\
\hline Introspection & $\begin{array}{c}2.56(.84) \\
2.67(2.00 ; 3.00)\end{array}$ & $\begin{array}{c}2.83(.72) \\
2.67(2.33 ; 3.33)\end{array}$ & $\begin{array}{c}2.68(.74) \\
2.67(2.33 ; 3.33)\end{array}$ & .055 \\
\hline Career/Job & $\begin{array}{c}2.80(1.05)^{\mathrm{d}} \\
3.00(2.00 ; 4.00)\end{array}$ & $\begin{array}{c}3.57(.68) \\
4.00(3.00 ; 4.00)\end{array}$ & $\begin{array}{c}3.24(.90) \\
4.00(3.00 ; 4.00)\end{array}$ & $.001 *$ \\
\hline Total & $\begin{array}{c}69.95(9.43) \\
71.00(64.00 ; 76.00)\end{array}$ & $\begin{array}{c}71.63(9.50) \\
72.00(64.50 ; 77.00)\end{array}$ & $\begin{array}{c}70,95(9.08) \\
72.00(64.75 ; 78.00)\end{array}$ & .331 \\
\hline
\end{tabular}

*Statistical difference $\mathrm{p}<0.05$ (Kruskal-Wallis test) between: a) Students and Professors; b) Professors with Students and Staff; c) Students with Professors and Staff; d) Students with Professors and Staff.

Furthermore, it was seen that sleep, seat belt usage, stress and safe sex (Figure 1) had a significant effect $(\mathrm{SE}=.17, \mathrm{CR}=-2.00 ; \mathrm{p}=.04)$ considering the satisfaction of the professors with their muscles, with $8 \%$ of shared variance [GFI=.99; CFI=1.00 RMSEA=0.09; $p=0.063]$. It is noteworthy that the increase of positive behavior related to sleep, use of seat belt, stress and safe sex has a moderate negative effect $(\beta$ $>.20$ ) on the self-evaluation of muscles. This finding indicates that the increase of 1 standard deviation considering the sleep, safety belt, stress, and safe sex fields causes a reduction of 


\section{Nascimento Filho, J.R.A.; Moreira, C.R.; Gonçalves, M.P; Bezerra, T.A.; Souza Filho, A.N.; Fiorese, L.; Carvalho, F.O}

.28 standard deviation on satisfaction with muscles.

Regarding the administrative staff (Figure 1), it was found that the alcohol, family and friends explained $9 \%$ of the variability for external parts satisfaction [GFI=1.00; CFI $=1.00$ RMSEA $=0.09$; $\mathrm{p}=0.009$ ]. Regarding the individual trajectories, it was found that the alcohol trajectory $(\mathrm{SE}=.08$, $\mathrm{CR}=3.20, \mathrm{p}=.001$ ), and family and friends $(\mathrm{SE}=.06, \mathrm{CR}=2.36 ; \mathrm{p}=.018)$ showed a significant effect, indicating that the decrease of alcohol consumption, in addition to the satisfaction with family and friends relationships has a moderate effect ( $\beta>$.20) on some parts of the body, such as hair, face and skin. This finding indicates that the increase of 1 standard deviation in the fields of alcohol and family/friends cause an increase of .25 and .19 standard deviation, respectively, considering the satisfaction with the external parts.

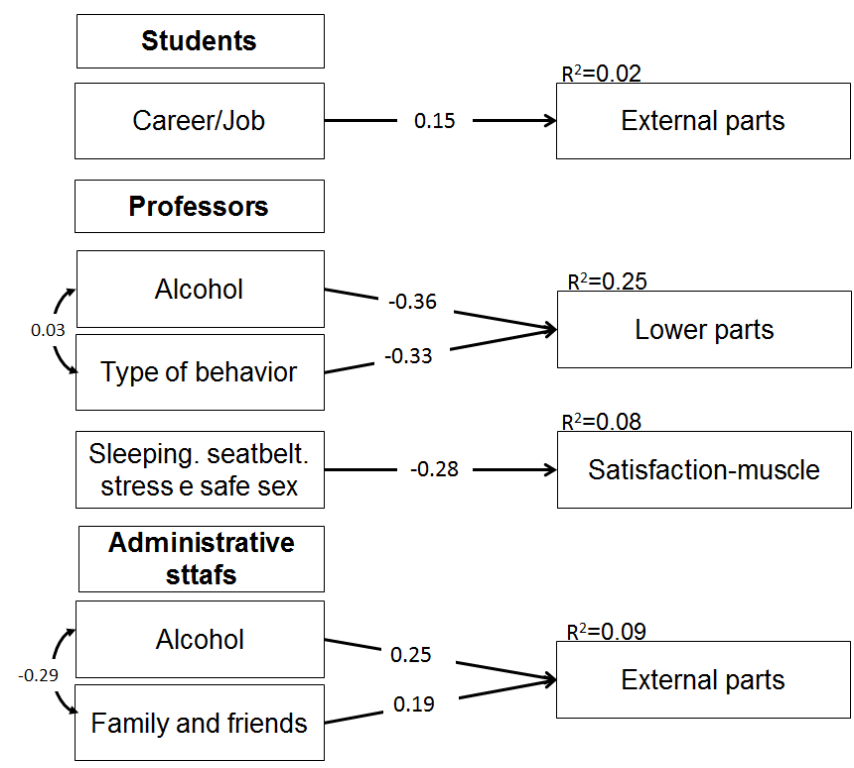

Figure 1. Path Analysis of the impact of lifestyle domains on the body satisfaction of students, professors and administrative staffs.

\section{DISCUSSION}

The present study investigated the impact of lifestyle perception over body satisfaction of students, professors and administrative staff of a Brazilian northeastern federal university, a subject that, although mostly investigated in women (Laus et al., 2014), lacks evidence regarding the influences of different perceptions among those involved in the university environment. In this sense, our findings contribute with evidences about how the particularities of lifestyle in the different sectors of the university may interfere in the body satisfaction of the people involved. In general, the involvement with work and personal relationships among friends and family members will favor the contentment with one's own body. In addition, in specific groups, some attitudes considered as unhealthy for lifestyle can also favor the satisfaction with the body image, something unexpected for body image outcome, which is usually related to positive and healthy attitudes.

Although this research partly reinforces that healthy attitudes and good relationships with people are promoters of a better sense of wellbeing and quality of life perception, leading to greater acceptance of one's body (Bednarzyk, Wright, \& Bloom, 2013; Nahas, Barros, \& Francalacci, 2000), an unprecedented result showed that unhealthy habits may also favor self-judgment. It was noticed that the professors of the institution were the ones who thought that negative effects on lifestyle could positively influence body satisfaction (Figure 1), whereas the administrative staff think that the use of alcohol is a factor that impairs a better satisfaction with the external parts of the body. This type of behavior, although it appears not to be conventional, may express the current manner through which this group of people face the perception of their own body. Some studies (Both, Nascimento, \& Borgatto, 2012; Oliveira Filho, Netto-Oliveira, \& Oliveira, 2012) show that professors seem to have an unhealthy lifestyle, with stress, sleep deprivation, and alcohol intake. These characteristics, for the present sample, did not seem to be hindering factors for body satisfaction; on the other hand, these are elements that can be connected to a 


\section{Lifestyle and body satisfaction in higher education}

broader view of what generates welfare for oneself.

This shows that a health-oriented behavior is not necessarily the only way for body satisfaction, since in addition to these factors, several others may influence this process. Quality of life can be an example, by arguing that the healthiest person does not necessarily have the best quality of life (Nahas, 2013). Therefore, this group does not seem to internalize media standards for body image and the means to achieve it. This can be associated with the sociocultural theory, since such theory indicates that when these physical standards are rather internalized, a discontent with one's own body will likely occur (Rodgers et al., 2011).

In contrast, some studies (Bednarzyk et al., 2013; Casquinho et al., 2013) indicated that the body satisfaction of adults is rather related to a healthy lifestyle, especially when they practice sport and care about health and nutrition habits. This controversy can be explained by the stage of life and socioeconomic status of higher education professors (Alfermann \& Stambulova, 2007), since they have a better economic stability and are in a moment of self acceptance with their own body, not caring so much about their attitudes and behaviors in daily life. This may indicate that professors may not be generally interested in exercises to be more satisfied with their bodies, although remaining interested in other benefits that physical exercise can promote.

However, the administrative staff showed that decrease in alcohol consumption and socializing with family and friends can contribute to a better perception of the body (Figure 1). In this perspective, the present study corroborates with most of the studies on this subject (Bednarzyk et al., 2013; Casquinho et al., 2013; Mendonça et al., 2012), and also evidences a relationship with the Nahas' Pentacle of Wel-Being (2013). This model argues that a healthy lifestyle is based on a good relationship with the people around you, preventive behavior, such as low alcohol consumption, and physical exercise, which favor the general well-being of the person and his/her own body. Thus, a lifestyle that includes these types of features may favor better personal acceptance and well-being, which can increase longevity (Nahas et al., 2000). When compared to Radel et al. (2017) study, this indicates a better possibility to integrate and remain in a physical exercise program as part of a daily routine. Moreover, if compared with sedentary people (Hernández \& Jiménez, 2013), those who are in a physical exercise program shows more attitudes to keep physical health than sedentaries.

When comparing the groups of the investigated academic community in relation to body satisfaction, the students were more dissatisfied with their own bodies (Table 1), mainly regarding external parts of the body, such as hair, face and skin, as well as the muscles in general. This shows a major characteristic of the age of this group, that is most oftenly interested in having a tanned body, fashion hair, proportional/symetrical faces, as well as more toned muscles (Ferrari et al., 2013; Damasceno, Vianna, Novaes, Lima, Fernandes, \& Reis, 2011). Thus, one can take into account the physical standards that society imposes on young people, something that, according to the sociocultural theory, considers to be an existing pressure that is different from one place to another (Groesz et al., 2002), and when internalized may increase body dissatisfaction (Rodgers et al., 2011). Additionally, the administrative staff were dissatisfied with body fat, with such being one of the reasons for practicing physical exercise, an argument intensively reported by this age group elsewhere (Liz \& Andrade, 2016; Santos \& Knijnik, 2006).

When verifying the academic community lifestyle (Table 2), students showed a higher frequency of unsafe actions, such as the non-use of seat belt, unsafe sex, sleep deprivation and increased aggressive behavior, in addition to a greater dissatisfaction with work. On the other hand, this was the most assiduous group to physical activity practice. These findings are 


\section{Nascimento Filho, J.R.A.; Moreira, C.R.; Gonçalves, M.P; Bezerra, T.A.; Souza Filho, A.N.; Fiorese, L.; Carvalho, F.O}

related to studies (Moraes, Laat, Lara, \& Leite, 2011; Paixão, Dias, \& Do Prado, 2010) that found that university students do not have a healthy lifestyle. This is due to the life phase these people are going through, since they try to experience a range of sensations and experiences at this phase, which may lead to the adoption of unsafe/risky behaviors. In addition, this group is more displeased with work, because the vast majority is still not effectively in the labor market or the individuals are at the beginning of their careers (Alfermann \& Stambulova, 2007). Thus, the financial return for this group is low, or at least lower than the professors' and administrative staff's, who may have higher salaries, more opportunities and better jobs within the institution.

It should also be observed that the professors seem to have a lifestyle that provides them with a higher alcohol consumption than the other groups studied (Table 2). This is a distinctive feature from other previous research findings (Paixão et al., 2010), since the students are the ones who usually have this behavior, not the professors. However, Oliveira Filho et al. (2012) showed that the higher education professors have alcohol consumption above what is recommended by the World Health Organization, which is consistent with our results. It is important to highlight that practice physical exercise routinely, like the subjects of the present study, is not enough to guarantee both habits and lifestyle healthy (Ayensa, Gonzáles Díaz, Ortiz, \& Andujo, 2011).

Although these relationships have already been partially verified (Bednarzyk et al., 2013; Casquinho et al., 2013; Oliveira Filho et al., 2012), new specificities of this study were reported in terms of the students, professors and administrative staff of higher education, implying in a possible differentiated study within the fitness centers with these individuals, since people who play different roles should be differently worked with (Alfermann \& Stambulova, 2007). Therefore, practice strategies should be suggested, as well as specific physical guidelines for each group and environment, so as a way to promote greater assiduity of the regular groups who practice physical exercise.

In addition, despite the contributions, some limitations should be discussed. First, the sample is related to a single higher education institution in the Northeast region of Brazil, which does not allow for the generalization of results for other populations. However, it is worth mentioning the large number of participants, possibly expanding our discussion within populations with similar specific characteristics. Moreover, also considering the study sample, only the individuals who regularly practice exercise were evaluated, failing to investigate those who do not. Therefore, a great extent of lifestyle influence on body satisfaction of this population was not taken in to account. Thus, is the inclusion of other portions of higher education population is suggested for future studies, since different results may be found for sedentary samples and from other regions of the country.

\section{PRATICAL APPLICATIONS}

The present study provides evidence that lifestyle profile is a determining factor for body satisfaction in higher education in different ways. It is noteworthy that body satisfaction has not been shown to be exclusively related to healthy habits. While students and administrative staff have a greater satisfaction with their body based on a healthy lifestyle, professors do not necessarily rely exclusively on this type of lifestyle to be satisfied with their own bodies. Therfore, for people who practice physical exercise routinely, body satisfaction can be favored independently of a single specific lifestyle. As practical implications of these results, further studies may consider physical exercise practice in other environments and with different groups and practitioners. Such studies should be conducted in order to promote a better understanding of healthy behavior related to lifestyle in order to develop strategies for better quality of life as well as greater self-satisfaction with one's body. 


\section{Lifestyle and body satisfaction in higher education}

\section{REFERENCIAS}

1. Abbott, B.D., \& Barber, B.L. (2011). Differences in functional and aesthetic body image between sedentary girls and girls involved in sports and physical activity: Does sport type make a difference? Psychology of Sport and Exercise, 12(3), 333-342.

DOI: 10.1016/j.psychsport.2010.10.005.

2. Alfermann, D., \& Stambulova, N. (2007). Career transitions and career termination. In G.Tenenbaum \& R.C. Eklund (Eds). Handbook of Sport Psychology (pp.712733). Hoboken, NJ:John Wiley \& Sons.

3. Añez, C.R.R., Reis, R.S., \& Petroski, E.L. (2008). Brazilian version of a lifestyle questionnaire: translation and validation for young adults. Arquivos Brasileiros de Cardiologia, 91(2), 102-109. DOI: 10.1590/S0066-782X2008001400006.

4. Bednarzyk, M.S., Wright, T.L., \& Bloom, K.C. (2013). Body image and healthy lifestyle behaviors of university students. Internation Jornal of Advanced Nursing Studies, 2(2), 107-114. doi: 10.14419/ijans.v2i2.1290.

5. Ayensa, J. I. B., González Díaz, A., Ortiz, C. R., \& Andujo, P. S. (2011). Imagen corporal, hábitos alimentarios y hábitos de ejercicio físico en hombres usuarios de gimnasio y hombres universitarios no usuarios. Revista de Psicología del Deporte, 20(2), 353-366.

6. Blanco, H., Benavides, E. V.,Tristan, J. L., Mayorga-Vega, D. (2017). Actividad física, imagen corporal y autoconcepto personal en jóvenes universitarias mexicanas. Revista de Psicología del Deporte, 26(s.2), 25-33.

7. Both, J., Nascimento, J.V., \& Borgatto, A.F. (2012). Estilo de vida dos professores de Educação Física ao longo da carreira docente no estado de Santa Catarina [Lifestyle of physical education teachers throughout the teaching career at santa catarina state]. Revista Brasileira de Atividade Física e Saúde, 12(3), 54-64. doi:10.12820/rbafs.v.12n3p54-64.
8. Cardoso, F.L., de Almeida Zequinão, M., Felizola, F.L.V., Ceola, E.P.A., \& Matos, P.H. (2011). Percepção e satisfação corporal em relação ao exercício físico [Perception and body satisfaction in relation to physical exercise]. Revista Brasileira de Atividade Física e Saúde, 16(2), 95-99. doi:10.12820/RBAFS.V.16N2P95-99.

9. Casquinho, J., Cheira, J., Roseiro, J., Neves, L., Martins, J., \& Marques, A.(2013). Relação entre a perceção de imagem corporal e a prática de atividade física formal e informal [Relationship between the body image perception and a formal and informal physical activity]. Revista da Sociedade Científica da Pedagogia do Desporto, 1(2), 304-311.

10. Damasceno, V. O., Vianna, J. M., Novaes, J. S., Lima, J. P., Fernandes, H. M., \& Reis, V. M. (2011). Relationship between anthropometric variables and body image dissatisfaction among fitness center users. Revista de Psicología del deporte, 20(2), 367-382.

11. Ferrari, E.P., Petroski, E.L., \& Silva, D.A.S. (2013). Prevalence of body image dissatisfaction and associated factors among physical education students. Trends in Psychiatry and Psychotherapy, 35(2), 119$127 . \quad$ doi: $10.1590 /$ S223760892013000200005.

12. Groesz, L.M., Levine, M.P., \& Murnen, S.K. (2002). The effect of experimental presentation of thin media images on body satisfaction: A meta-analytic review. International Journal of Eating Disorders, 31(1), 1-16. doi: 10.1002/eat.10005.

13. Guedes, D. P. \& Grondin, L. M. V. (2002). Percepção de hábitos saudáveis por adolescentes: associação com indicadores alimentares, prática de atividade física e controle de peso corporal [Perception of health custons by adolescents: association among eatings indicatives, practice of physical activity and control of corporal weight]. Revista Brasileira de Ciência $e$ Esporte, 24(1), 23-45. 


\section{Nascimento Filho, J.R.A.; Moreira, C.R.; Gonçalves, M.P; Bezerra, T.A.; Souza Filho, A.N.; Fiorese, L.; Carvalho, F.O}

14. Hernández, I. C., \& Jiménez, J. M. (2013). Relación entre el grado de actividad física y la satisfacción sexual y corporal en estudiantes universitarios costarricenses. Cuadernos de Psicología del Deporte, 13(1), 15-24.

15. Hirata, E., \& Pilati, R. (2010). Desenvolvimento e validação preliminar da Escala Situacional de Satisfação CorporalESSC [Development and preliminary validation of the Body Satisfaction Situational Scale - ESSC]. Psico USF, 15(1), 1-11. doi: 10.1590/S141382712010000100002 .

16. Kline, R.B. (2012). Principles and practice of structural equation modeling. New York: The Guilford Press.

17. Laus, M.F., Kakeshita, I.S., Costa, T.M.B., Ferreira, M.E.C., Fortes, L.D.S., \& Almeida, S.S. (2014). Body image in Brazil: recent advances in the state of knowledge and methodological issues. Revista de Saúde Pública, 48(2), 331-346. doi: 10.1590/S0034-8910.2014048004950.

18. Liz, C.M., \& Andrade, A. (2016). Análise qualitativa dos motivos de adesão e desistência da musculação em academias [Qualitative analysis of the reasons to the adhesion and desistance to the practice of resistance exercises in gyms]. Revista Brasileira de Ciênciencias do Esporte, 38(3), 267-274. doi: 10.1016/j.rbce.2015.11.005.

19. Marôco, J. (2011). Análise estatística com o SPSS Statistics. Pêro Pinheiro, Portugal: ReportNumber.

20. Mendonça, R.M.S.C., Sousa, M.S.C., \& Fernandes, H.M. (2012). Influência de diferentes programas de exercício físico na composição corporal e dimensões psicológicas em mulheres [Influence of different programs of physical exercise in body composition and psychological dimensions in women]. Motricidade, 8(2), 1023-1031.

21. Moraes, M., Laat, E.F., Lara, L., \& Leite, G.T. (2011). Consumo de álcool, fumo e qualidade de vida: um comparativo entre universitários [Consumption of alcohol, tobacco and quality of life: a comparative degree enters the academics]. Cinergis, 11(1), 85-94. doi: 10.17058/cinergis.v11i1.2177.

22. Nahas, M.V., Barros, M.V.G., \& Francalacci, V. (2000). O pentáculo do bemestar - base conceitual para avaliação do estilo de vida de indivíduos ou grupos [The pentacle of well-being - conceptual basis for assessing the lifestyle of individuals or groups]. Revista Brasileira de Atividade Físisica e Saúde, 5(2), 48-59. doi: 10.12820/RBAFS.V.5N2P48-59.

23. Nahas, M.V. (2013). Atividade Física, Saúde e Qualidade de Vida. 6 ed. Londrina, PR: Midiograf.

24. Neves, D.R., Martins, É.A., Souza, M.V.C., \& Junior, A.J.S. (2015). Efeitos do treinamento de força sobre o índice do percentual de gordura corporal em adultos [Effects of strength training on the body fat percentage in adults]. Revista Brasileira de Obesidade, Nutrição e Emagrecimento, 9(52), 135-141.

25. Oliveira Filho, A., Netto-Oliveira, E.R., \& Oliveira, A.A.B. (2012). Qualidade de vida e fatores de risco de professores universitários [Quality of life and risk factors of university professor]. Revista da Educação Física/UEM, 23(1), 57-67. doi: 10.4025/reveducfis.v23i1.10468.

26. Paixão, L.A., Dias, R.M.R., \& Do Prado, W.L. (2010). Estilo de vida e estado nutricional de universitários ingressantes em cursos da área de saúde do Recife/PE [Lifestyle and nutritional status of university students studying in health care in Recife/PE]. Revista Brasileira de Atividade Físisica e Saúde, 15(3), 145-150. doi:10.12820/RBAFS.V.15N3P145-150.

27. Pletsch, G.M.C., Reuter, É.M., Lasch, E.F., Vieira, F.M., Reckziegel, M.B., \& Pohl, H.H. (2014). Estilo de vida de trabalhadores e sua relação com índice econômico e setor produtivo [Lifestyle workers and their relationship with economic and productive 


\section{Lifestyle and body satisfaction in higher education}

sector index]. Cinergis, 15(2), 58-64. doi: 10.17058/cinergis.v15i2.4368.

28. Radel, R., Pelletier, L., Pjevac,D., \& Cheval,B. (2017). The links between selfdetermined motivations and behavioral automaticity in a variety of real-life behaviors. Motivation and Emotion, 41 (4), 443-454. doi: 10.1007/s11031-017-9618-6

29. Rodgers, R., Chabrol, H., \& Paxton, S.J. (2011). An exploration of the tripartite influence model of body dissatisfaction and disordered eating among Australian and French college women. Body Image, 8(3), 208-215.doi: 10.1016/j.bodyim.2011.04.009.

30. Rosa, A., García Cantó, E., \& Carrillo, P. J. (2018). Percepción de salud, actividad física y condición física en escolares. Cuadernos de Psicología del Deporte, 18(3), 179-189.

31. Santos, S.C., \& Knijnik, J.D. (2006). Motivos de adesão à prática de atividade física na vida adulta intermediária [Reasons for adherence to physical activity in middle adult life]. Revista Mackenzie de Educação Física e Esporte, 5(1), 23-34.

32. Santos, E. M., Tassitano, R. M, Nascimento, W. M. F, Petribú1, M. de M. V. \& Poliana,
C. C.(2011). Satisfação com o peso corporal e fatores associados em estudantes do ensino médio [Body satisfaction and associated factors among high school students]. Revista Paulista de Pediatria, 29(2), 214-23.

33. Shirasawa, T., Ochiai, H. Nanri, H., Nishimura, R. Ohtsu, T., Hoshino, H., Tajima, N. \& Kokaze, A. (2015). The relationship between distorted body image and lifestyle among Japanese adolescents: a population-based study. Archives of Public Health, 73, 32. doi:10.1186/s13690-0150082-z

34. Silva, A.M.M., Brito, I.S., Amado, J.M.C. (2014). Translation, adaptation and validation of the Fantastic Lifestyle Assessment questionnaire with students in higher education. Ciência \& Saúde Coletiva, 19(6), 1901-1909. doi: 10.1590/141381232014196.04822013.

35. Wilson, D.M.C., Nielsen, E., \& Ciliska, D. (1984). Lifestyle assessment: testing the FANTASTIC instrument. Canadian Family Physician, 30(9), 1863-1866. 